\title{
The effective use of feedback in health professions teaching
}

\author{
O uso eficiente do feedback no ensino de profissionais de saúde \\ El uso eficaz de la retroalimentación en la \\ enseñanza de las profesiones sanitarias
}

David W. Musick*

\begin{abstract}
The purpose of this review is to define feedback and provide informed commentary on how feedback should be given to health professions learners during the educational process. The purpose of feedback is to enhance and improve student learning; this is in contrast to grading, which has the purpose of summarizing what a student has learned during a given educational experience. Feedback is highly influenced by other characteristics of the educational setting (e.g., clarity of objectives, context of learning, timing, and specificity). Both students and faculty members have a responsibility to seek and provide feedback within the context of the teaching relationship. Surprisingly few research studies exist concerning how feedback impacts learning outcomes. Surveys have shown that feedback is highly desired by students and yet often felt to be inadequately given. Simultaneously, faculty members often feel that feedback given is of good quality but has not been recognized by students. Factors that impede good feedback in the clinical teaching setting include teacher preparation, student characteristics, the learning environment and time pressures. There is evidence that student expectations concerning the type of feedback they desire change over time, i.e., as the student progresses through the curriculum. It is strongly suggested that the quality of feedback impacts student learning, perhaps more than any other aspect of the teaching process. Best practices associated with giving and receiving feedback have been identified, but faculty development in this regard may be lacking. Recommendations to students and faculty members alike may help alleviate problems with the feedback process and serve to facilitate more effective learning.
\end{abstract}

Keywords: Feedback; Formative feedback; Clinical teaching; Student learning.

\section{Resumo}

O objetivo desta revisão é definir feedback e fornecer comentários apropriados sobre a forma como o feedback deve ser dado a estudantes da área de saúde durante o processo educacional. O objetivo do feedback é aumentar e melhorar a aprendizagem dos alunos; em contraste com o exame ou teste que classifica e tem o objetivo de resumir o que o aluno aprendeu durante uma determinada experiência educacional. Feedback é altamente influenciado por outras características do ambiente educacional (por exemplo, a clareza de objetivos, o contexto de aprendizagem, o tempo e a especificidade). Ambos, alunos e professores, têm a responsabilidade de buscar e fornecer feedback no contexto da relação de ensino. Surpreendentemente existem poucos estudos a respeito do impacto do feedback na aprendizagem. Pesquisas têm mostrado que o feedback é muito desejado pelos alunos e, no entanto, muitas vezes há a percepção de ser inadequadamente oferecido. Ao mesmo tempo, docentes muitas vezes sentem que o feedback dado é de boa qualidade, mas não é reconhecido pelos estudantes. Fatores que impedem o bom feedback no ambiente de ensino clínico incluem a preparação do professor, as características dos alunos, o ambiente de aprendizagem e as pressões de tempo. Há evidências de que as expectativas dos alunos sobre o tipo de feedback desejado muda ao longo do tempo, ou seja, varia ao aluno progredir no currículo.

Fortes evidências sugerem que a qualidade do feedback impacta a aprendizagem dos alunos, talvez mais do que qualquer outro aspecto do processo de ensino. Melhores práticas associadas a dar e receber feedback foram 
identificados, mas o desenvolvimento do corpo docente a este respeito continua incompleto. Recomendações aos discentes e docentes podem ajudar a aliviar problemas com o processo de feedback e servem para facilitar a uma aprendizagem mais eficaz.

Descritores: Feedback; Feedback formativo; Ensino clínico; Aprendizado do estudante.

\section{Resumen}

El propósito de esta revisión es el de definir la retroalimentación y proveer comentarios que aporten más información sobre la forma de retroalimentación que se debe dar a los estudiante de las profesiones sanitarias durante el proceso educacional. El propósito de la retroalimentación es el de incrementar y perfeccionar el aprendizaje del estudiante; esto contrasta con la calificación, la que tiene el propósito de resumir lo que un estudiante ha aprendido durante una experiencia educativa dada. La retroalimentación es altamente influenciada por otras características del entorno educativo (ejemplo: claridad en los objetivos, contexto de aprendizaje, ritmos y especificidad). Tanto los estudiantes como los miembros de facultad tienen la responsabilidad de buscar y proporcionar retroalimentación dentro del contexto de la relación de enseñanza. Sorprendentemente, solo existen algunos estudios de investigaciones sobre cómo la retroalimentación impacta en los resultados del aprendizaje. Las encuestas demuestran que la retroalimentación es altamente deseada por los estudiantes, pero a menudo se considera como dada inadecuadamente. Simultáneamente, los miembros de la facultad a menudo consideran que la retroalimentación dada es de buena cualidad, pero que no es reconocida por los estudiantes. Los factores que impiden una buena retroalimentación en el ambiente de enseñanza clínica incluye la preparación del maestro, las características de los estudiantes, el ambiente de aprendizaje y presiones de tiempo. Hay evidencia de que las expectativas de los estudiantes con respecto al tipo de retroalimentación deseada cambian con el tiempo, ejemplo: cuando el estudiante progresa a través del plan de estudio. Se debe recordar de sobremanera que la calidad de la retroalimentación impacta el aprendizaje del estudiante, tal vez más que cualquier otro aspecto del proceso de aprendizaje. Mejores prácticas asociadas con dar y recibir retroalimentación han sido identificadas, pero la formación docente a este respecto puede ser que esté faltando. Las recomendaciones a los estudiantes y a los miembros de la facultad por igual pueden ayudar a atenuar los problemas con el proceso de retroalimentación y sirven para facilitar el aprendizaje más eficaz.

Palabras clave: Retroalimentación; Retroalimentación formativa; Enseñanza clínica; Aprendizaje del estudiante.

\section{Introduction}

There once was a small boy who told his friend, "I taught my dog Rover to whistle." His friend leaned down in front of the dog and listened for a few moments, hearing nothing. He finally said to the dog's owner, "I don't hear him whistling." His friend replied, "I said I taught him; I didn't say he learned it."

Does this sound familiar? Sadly, there is often truth to this illustration about the difference between teaching and learning. How can we know when our students have learned what we hoped to teach them? And how does a given learner determine whether s/he has learned everything expected? I would submit that much of the success in the learning process depends on the effectiveness of feedback. The purpose of this article is to discuss the importance of feedback to the learning process and how to ensure that feedback is given effectively.

\section{Feedback defined}

What is "feedback"? In a classic article in a prominent medical journal, feedback is defined as "information describing students' or house officers' performance in a given activity that is intended to guide their future performance in that same or in a related activity". Put another way, feedback is "information about someone's current performance that can be used to improve it in the future". ${ }^{2}$ Feedback has also been aptly defined as "specific information about the comparison between a trainee's observed performance and a standard, given with the intent to improve the trainee's performance." ${ }^{3}$ Very simply, the purpose of giving feedback is to improve student learning. While it seems obvious that giving feedback to students is critically important (especially in the realm of health professions education), surprisingly little formal research has examined the link between feedback and learning outcomes. 
Opinion surveys on feedback tend to reveal two general trends: one, students are highly desirous of feedback and can become agitated if they don't receive it; and two, there is often disagreement between students and their teachers about whether students received good feedback during a given learning experience.

Each spring in the United States, all graduating seniors from US allopathic medical schools complete a national survey concerning various aspects of their 4-year medical school experience. This survey, known as the Graduating Student Questionnaire, asks students to state whether "faculty members provided me with sufficient feedback on my performance" during third year core clinical clerkship rotations using a standard, Likert-type rating scale. For the Spring 2013 survey, the average percentage of students who either agreed or strongly agreed with this statement across all year three clinical clerkships was $78 \%$. Interestingly, responses ranged from a high of $86 \%$ (Internal Medicine) to a low of $66 \%$ (Surgery). ${ }^{4}$ These data illustrate that student opinion concerning feedback may vary depending on the learning context.

\section{The learning context and its impact on feedback}

Feedback is closely related to the context and purpose of a given course of study. ${ }^{5} \mathrm{~A}$ basic requirement is that the educational objectives of a learning experience must state clearly what students are expected to learn in specific terms. There are several consequences that result when educational objectives are unclear. First, student learning is not maximized. Students cannot learn that which they do not know they are expected to learn. Second, when the learning objectives are not clear students are left to wonder what they are supposed to learn. For example, some medical students may report anecdotally that they began a clinical rotation with little or no idea about what is expected of them. While well intentioned faculty members may feel that the student must practice "self-guided learning" as part of his/her education, this does not include expecting students to independently determine what faculty members expect them to learn during a given course or clinical rotation. Every learning situation requires a clear statement of expectation (i.e., objectives) for what should be learned. Most often, these statements are found in a course syllabus or similar document. Third, in the absence of clear objectives, students will likely become frustrated, which further impedes their learning. They may become beset with uncertainty, and may over-react to any small "clue" about what they are supposed to learn or do. And, in such an environment, the importance of written exams may become even more inflated than normal. This, in turn, increases everyone's anxiety levels and may result in the assumption of cynical attitudes toward the learning process as a whole. ${ }^{6}$

Basic reasons for giving feedback are that it reinforces effective behavior and facilitates change in ineffective behavior. In the context of a basic science classroom-based course, a student may be expected within a certain time period to learn the material covered in assigned textbook chapters plus a set of lectures, after which they will take an exam. In this context there are several methods that can be used to enhance student learning via feedback. For example, most students are inquisitive and will often want to ask clarifying questions during presentations. Conducting class sessions in a manner that encourages students to ask cogent questions on lecture material is a method of facilitating effective feedback. It allows the teacher to further amplify the material, correct any misconceptions and keep the student "on the right track" by providing answers to their questions.

Examinations also provide opportunities for students to demonstrate whether they are learning the material effectively. As soon as practical after written examinations are scored, teachers should schedule a formal "feedback session" and go over the exam in detail, presenting the correct answers and allowing students to ask questions about items missed. Examinations themselves can be scored in such a manner as to provide subject-oriented feedback to students. ${ }^{7}$ For example, on a typical 100-item anatomy exam, there will likely be questions that cluster around given subjects (e.g., anatomy of the head and neck; anatomy of the lower extremities). These items can be scored as subgroups of the overall exam. In addition to 
an overall exam score, students can also be given a score for each subgroup; this, in turn, allows students to see where their relative strengths and weaknesses are in terms of subject areas. Providing feedback through answering questions and scoring subject areas within exams are means of reinforcing student learning, facilitating change in students' study habits and directing their future efforts toward areas of relative weakness. Courses that simply post exam scores, without feedback sessions or any opportunity for students to understand specific content areas where they performed well or need improvement, do not take advantage of the opportunity to furnish feedback.

In the clinical realm feedback is most often focused on specific issues pertaining to patient care and what is expected of students in the clinical setting. One study of medical students found that early during the core clerkship year, students' desire for feedback focused more on their roles in the care of patients; as the year progressed, they desired more detailed feedback on physical exam skills, communication or both. ${ }^{8}$ A different study found that providing weekly email messages to resident physicians about how and when to give feedback to medical students resulted in significant improvements to the frequency and quality of feedback given. ${ }^{9}$ Again, it is necessary to clearly identify occasions when feedback can be most effectively provided to students by a variety of methods. When the process of feedback is structured appropriately, the result will be that both teachers and learners gain important knowledge and motivation toward success.

\section{Giving good feedback in the clinical setting}

In addition to the previously stated suggestions, here are some tips that are especially relevant to giving feedback in the clinical teaching realm. These tips are based on an overall review of the medical education literature, with particular reference to an oft-cited review article on workplace-based assessment ${ }^{10}$ :

1. Focus on behaviors that you have personally observed and that the student can control or improve upon.

2. Focus on decisions and actions, rather than your own perceptions or what you feel the student's intent was (which may be difficult to know).

3. Be as specific as possible; do not talk in generalizations (e.g., "your differential diagnosis is inadequate"), but rather tell the student what was lacking (e.g., "your differential diagnosis did not include the possibility of tuberculosis").

4. Feedback should be well-timed, preferably built into the schedule so that students expect it and know when it is to occur.

5. If possible, give feedback in a more relaxed atmosphere (e.g., a private office), rather than in a stressful, busy environment with lots of other people around.

6. Ask the student how s/he feels they performed; they will often realize what they did incorrectly and, thus, make it easier for you to discuss.

7. Be sure the student knows what $s /$ he did correctly; it is better to say "your case presentation gave me an accurate, detailed picture of the patient's problem", rather than saying "you were great when you presented that case".

8. Try the "feedback sandwich" model: start with something positive that the student did well, follow with something they need to improve upon, and finish by re-stating what they did well. However, be certain that the positive feedback is genuine, and not about something trivial, or else they will quickly see that you are trying to feed them a "baloney sandwich"! Again, positive feedback focuses on very specific things that they did well.

\section{Receiving feedback}

What can students do to make the feedback process work more effectively? Here are some tips for students who desire to obtain feedback on their learning:

1. Recognize the challenges of the educational environment. Clinical faculty as well as resident physicians are most often extremely busy; time must be managed well and, in particular, teaching time must be focused and to 
the point. The same thing is true in the basic sciences; faculty members are often challenged by multiple priorities (e.g., teaching, research, administrative or service work). This means that you must be present and fully engaged during "teachable moments".

2. Ask for feedback! Don't hesitate to approach teaching faculty and ask them for input on your performance. Remember, you cannot achieve your learning objectives if you don't know what they are; nor if you are unsure of how to proceed. While faculty should make the educational objectives clear, this sometimes doesn't happen for a variety of reasons. If you aren't sure what you are supposed to do or learn, don't hesitate to ask questions in a positive manner. For example, you can ask "did I accomplish what I should have in that situation?" or "how can I improve on this task next time around?" Faculty will generally appreciate your openness to feedback and find it easier to provide it if you ask.

3. When you ask for feedback, be as specific as possible. For example, suppose you just finished taking a history and performing a physical exam on a patient, with a resident or attending physician observing your performance. Ask for specific information on what you did well, as well as on what you could improve. Instead of asking "how did I do?" ask "how well did I examine that patient?" or "was my exam thorough enough?" The more specific your question, the more likely you will receive effective feedback.

4. Remember that receiving feedback requires maturity, patience, and thoughtfulness. Much of the learning process involves a positive relationship between teacher and student. Work hard at having such relationships with those in the teaching role. And try to avoid an overly emotional response to feedback; the ability to handle constructive criticism is a sign of maturity. Becoming defensive or feeling a need to justify your actions, even if you believe the feedback is overly critical or uninformed, will inhibit the learning process.

5. At the same time, realize that receiving feedback is very different from feeling humilia- ted, harassed or otherwise belittled. Faculty members are encouraged to provide feedback on your performance; to do so in a private setting whenever possible; and to distinguish between a student's performance and their personhood. Deliberately humiliating a student in front of a peer group is rarely an effective teaching method; faculty should avoid such tactics. If you feel that you have been mistreated, don't hesitate to discuss this with someone in a position to address the situation (e.g., a course director, ombudsperson or school administrator).

\section{Conclusion}

Why don't we do a better job in giving and receiving feedback? Interestingly, at least one study indicates that student satisfaction with feedback may not be the best indicator of whether feedback was of high quality and demonstrates the complexity of this issue." A similar study investigated the difference between giving medical students feedback versus simple compliments on performance, and found that while student satisfaction was higher in the group receiving compliments, there was significant knowledge gain among students who received structured feedback.12 For faculty, there may be a lack of knowledge concerning the importance of feedback and how to give/ receive it. Often, faculty members state that they are hesitant to give honest feedback for fear that they may do more harm than good; this relates to the earlier point made about student reactions being overly emotional or defensive. For students, a hesitancy to admit shortcomings, or to ask for feedback on specific deficits in knowledge/skills, also contributes to a less than ideal approach to feedback. And the structure of a typical large, multispecialty academic medical center presents inherent challenges to the teaching and learning process, by virtue of the size and complexity of such organizations. Time pressures are real and may result in a lack of time for teaching, including giving feedback on performance. However, we must find ways to overcome these obstacles.

Feedback is a crucial element in the teaching and learning process. Good feedback will contribute to our students' development of lifelong learning habits, intellectual curiosity and the ability to 
become autonomous learners. Remember that the purpose of feedback is to enhance and improve student learning. With practice, you can become proficient at giving feedback to your learners and students can improve their abilities in recognizing and acting upon it.

\section{References}

1. Ende J. Feedback in Clinical Medical Education. JAMA 1983;250(6):777-81.

2. Whitman N. The Chief Resident as Manager. Salt Lake City, UT: University of Utah Press. 1988; 143p.

3. van de Ridder JM, Stokking KM, McGaghie WC, ten Cate OT. What is Feedback in Clinical Education? Med Educ 2008;42(2):189-97.

4. Medical School Graduation Questionnaire: 2013 All Schools Summary Report (July 2013). Accessed: December 27, 2013. Available at: https://www.aamc. org/data/gq/allschoolsreports/\#.Ur2jw7Qz-ZQ

5. Watling C, Driessen E, van der Vleuten CP, Vanstone M, Lingard L. Beyond Individualism: Professional Culture and its Influence on Feedback. Medical Education 2013; 47(6): 585-94.

6. White CB, Gruppen L, Fantone JC (2014). Self-Regulated Learning in Medical Education. In T. Swanwick (editor), Understanding Medical Education: Evidence, Theory and Practice. Malden, MA. Wiley-Blackwell Publishers.
7. Osterlind SJ. Judging the Quality of Test Items: Item Analysis (Chapter Eight). In Constructing Test Items: Multiple-Choice, Constructed Response, Performance and Other Formats (second edition). Boston: Kluwer Academic Publishers. 1998; p253-99.

8. Bing-You RG, Stratos GA. Medical Students' Needs for Feedback From Residents During the Clinical Clerkship Year. Teach Learn Med. 1995;7(3):172-6.

9. Matzie KA, Kerfoot BP, Hafler JP, Breen EA. Spaced Education Improves the Feedback that Surgical Residents Give to Medical Students: A Randomized Trial. Am J Surg. 2009;197(2):252-7. http://dx.doi. org/10.1016/j.amjsurg.2008.01.025

10. Norcini J, Burch V. Workplace-Based Assessment as an Educational Tool: AMEE Guide No. 31. Medical Teacher. 2007;29(9):855-71.

11. Boehler ML, Rogers DA, Schwind CJ, Mayforth R, Quin J, Williams RG et al. An Investigation of Medical Student Reactions to Feedback: A Randomised Controlled Trial. Med Educ. 2006;40(8):746-9.

12. Rogers DA, Boehler ML, Schwind CJ, Meier AH, Wall JC, Brenner MJ. Engaging Medical Students in the Feedback Process. Am J Surg. 2012;203(1):21-5.

\section{David W. Musick}

Department of Internal Medicine. Virginia Tech Carilion School of Medicine. Roanoke, VA, United States. 